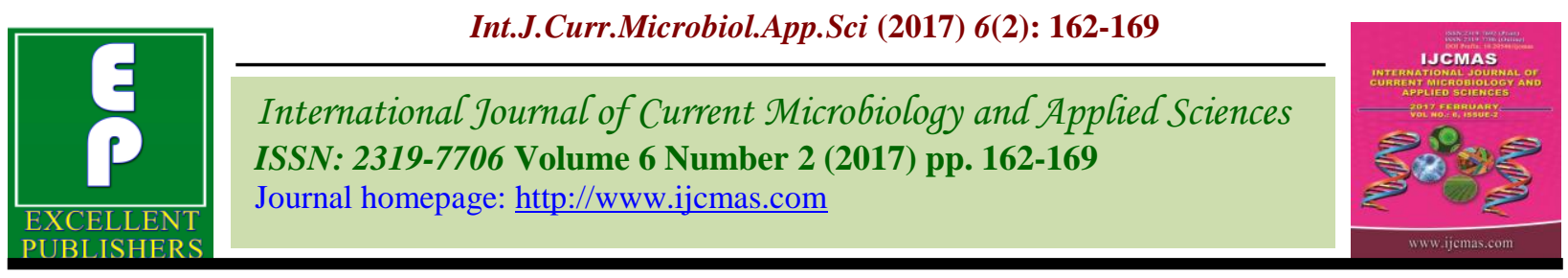

Original Research Article

http://dx.doi.org/10.20546/ijcmas.2017.602.023

\title{
Functional Properties of Spore-Forming Bacillus Strains: Pre-requisite for Probiotic Functions
}

\author{
Lopamudra Haldar ${ }^{1 *}$, D.N. Gandhi and Debasis Mazumdar ${ }^{2}$ \\ ${ }^{1}$ Department of Dairy Microbiology, Faculty of Dairy Technology, West Bengal University of \\ Animal and Fishery Sciences, Mohanpur- 741252, Nadia, West Bengal, India \\ ${ }^{2}$ Department of Agricultural Statistics, Faculty of Agriculture, Bidhan Chandra Krishi \\ Viswavidyalaya, Mohanpur- 741252, Nadia, West Bengal, India \\ *Corresponding author
}

\section{A B S T R A C T}

\begin{tabular}{|l|}
\hline Ke y w o r d s \\
Probiotics, Bacillus \\
species, Acid salt \\
tolerance, Bile salt \\
tolerance, Cell \\
surface \\
hydrophobicity, Rate \\
of acid production. \\
\hline Article Info \\
\hline $\begin{array}{l}\text { Accepted: } \\
\text { 12 January } 2017 \\
\text { Available Online: } \\
\text { 10 February } 2017\end{array}$ \\
\hline
\end{tabular}

Keywords

Probiotics, Bacillus species, Acid salt tolerance, Bile salt tolerance, Cell surface hydrophobicity, Rate of acid production.

Accepted:

Available Online:

\section{Introduction}

Probiotics are defined as "live microorganisms which, when administered in adequate amounts, confer a health benefit on the host" (FAO/WHO, 2002). Worldwide, most commonly used microbes as probiotics include many species of the genera, Lactobacilli and Bifidobacterium, Enterococcus, Streptococcus and fungi like Saccharomyces (Kumari et al., 2011). However, most are unstable at room temperature and need to be freeze dried or encapsulated via special processes to remain viable during manufacturing, storage and exposure to stomach acid and bile (Baick and Kim, 2015). The development and use of spore forming bacteria, Bacillus spp. in particular, as probiotic has brought a breakthrough in the probiotic world for both humans and animals (Cutting, 2011). Bacillus species have some attractive properties like ability to form spores during adverse conditions, higher resistance to technological 
stresses during production and storage processes (Jurenka, 2012) and also higher resistance to gastric ( $\mathrm{pH}$, digestive enzymes) and intestinal environmental conditions (Hong et al., 2005).

Probiotic microorganisms must have tolerance to acid and bile during passage through the gastro intestinal (GI) tract ensuring that the organisms could adhere within the gut (Shobharani and Halami, 2014). The ability of acid production such as, lactic acid, acetic acid etc. helps probiotic microorganisms to exert many beneficial effects including antimicrobial activity, imparting proper body, texture and flavour in fermented product preparation (Sidira et al., 2015). It is thus essential to select probiotic strain on the basis of acid, bile tolerance, adherence property along with acid production ability under in-vitro conditions. In the present study, we thus planned to investigate functional properties of some indigenous Bacillus isolates for screening the probable probiotic candidates.

\section{Materials and Methods}

An array of tests under in vitro conditions was conducted as per FAO/WHO (2002) to investigate functional properties of some indigenous Bacillus isolates at National Dairy Research Institute, Karnal- 132001, Haryana, India.

\section{Bacterial strains}

Forty seven Bacillus isolates covering Bacillus coagulans, Bacillus pumilus and Bacillus subtilis were collected from milk, soil and tomato sources and subsequently characterized morphologically, biochemically and genetically using single strand conformational polymorphism (SSCP) banding patterns and partial 16S rRNA gene sequences, as previously reported (Haldar et al., 2015). All Bacillus isolates were maintained on Bacillus coagulans agar (BCA) slants (Atlas, 2004) and sub-cultured after every $25-30 \mathrm{~d}$ period. These forty seven Bacillus isolates were screened for functional properties.

\section{Acid and bile tolerance test}

The acid (pH to 1.0, 2.0 and 3.0) and bile tolerance (1.0 and 2.0\%) of different Bacillus isolates were assessed as per the methods described previously (Clark et al., 1993; Clark and Martin, 1994).

\section{Surface hydrophobicity}

The bacterial adhesion to hydrocarbon like Nhexadecane is considered as a biochemical marker for its adherence ability to the epithelial cells of the gastro intestinal tract. The bacterial adhesion to hydrocarbon like Nhexadecane was determined by employing the standard method (Rosenberg et al., 1980) with slight modification to measure the cell surface hydrophobicity.

\section{Rate of acid production}

The freshly grown and active bacterial culture at $1 \%$ was mixed well with $10 \mathrm{ml}$ of sterilized skim milk and incubated at $37^{\circ} \mathrm{C}$ for $24 \mathrm{~h}$. The aqueous content was titrated against N/10 $\mathrm{NaOH}$ with $0.5 \%$ phenolphthalein indicator to determine the rate (in percent) of lactic acid production.

\section{Statistical analysis}

Since the in vitro studies of acid and bile tolerance, surface hydrophobicity and rate of acid production ability of 47 Bacillus isolates generated a huge set of data, it was difficult to screen the desired isolates apparently. The data generated from in vitro studies were 
subjected to multivariate principal component analysis (PCA) with a varimax procedure of factor analysis technique based upon correlation matrix using SPSS 10.0 Statistical Software Package, 1997, SPSS, Inc., USA, for primary screening of the isolates. The correlation matrix analysis allowed to construct minimum data set (MDS) consisting of only those variables, which accounted for maximum variation of the total variance of this experiment. The observed values of all isolates for only those MDS variables were considered and a criteria like highest value was best for each MDS variable was imposed to score all isolates on the basis of the weighted linear indexing method, where linear scores were weighted by explained variance of each representative component to total variation explained. The weighted linear scoring was used to rank first 10 Bacillus isolates.

\section{Results and Discussion}

The criteria for screening probiotics such as resistance to acid, bile tolerance, surface hydrophobicity for adhesion property, and acid production potential were studied under in vitro conditions with 47 Bacillus isolates.

\section{Acid tolerance to simulated $\mathrm{pH}$ of the human stomach}

The acid tolerance pattern of 47 Bacillus isolates is presented in table 1. Isolate B9 appeared to be the most acid tolerant, surviving even after $3 \mathrm{~h}$ at $\mathrm{pH} \mathrm{1.0,} \mathrm{though}$ more than 4 log cycle reduction was evident. Isolates, namely T15, T19, T23, CR2 and C8 survived at $\mathrm{pH} 1.0$ after $2 \mathrm{~h}$ of incubation. B48 appeared as the most sensitive among the set which could not survive $\mathrm{pH} 1.0$ at all. In most of the cases, the viable cell count reduced drastically in $1.0 \mathrm{pH}$ even at $0 \mathrm{~h}$. and all the strains showed decrease in viable cell count at $\mathrm{pH} 1.0$ by more than 4-5 log cycles. However, the strains could survive well at $\mathrm{pH}$
3.0 with only $1-2 \quad \log$ reduction, and moderately at $\mathrm{pH} 2.0$ to $2-3 \log$ reduction, except T7 which exhibited more than 4 log cycle reductions at both the $\mathrm{pH}$ followed by immediate exposure. The present findings agree well with the earlier report (Fontana et al., 2013). In another study (Hyronimus et al., 2000), different strains of $B$. coagulans, $B$. laevolacticus and $B$. racemilactiticus were sensitive to low $\mathrm{pH}$ (2.5 and 3) after 3 or $6 \mathrm{~h}$ of incubation, while $B$. subtilis survived at $\mathrm{pH}$ 2.0 and 3.0 and the survival percentage decreased $(P<0.05)$ when the exposure time progressed from 1 to $4 \mathrm{~h}$ (19). In the present study, there was a wide variation in response to acidic environments within different Bacillus strains.

Bile tolerance to simulated bile concentrations of the human small intestine

The bile salt tolerance pattern of different Bacillus strains is presented in table 2. Bile plays an important role in the digestion of food in the intestine. The rate of secretion of bile and the concentration of bile in different regions of the intestine can range between 0.5 to 2.0 percent during the first hour of digestion; the levels may decrease during the second hour. A period of $12 \mathrm{~h}$ has been reported as sufficient time for most foods to pass through the small intestine (Clark and Martin, 1994). Keeping in view these observations, an in vitro experiment was designed to examine the tolerance of Bacillus isolates in the presence of 1.0 and 2.0 percent of bile during a period of total $12 \mathrm{~h}$ of exposure at $37^{\circ} \mathrm{C}$. It revealed considerable changes in count in 1.0 and 2.0 percent bile salt concentrations at different time intervals. Approximately 1-2 log reduction in $1.0 \%$ bile salt concentration at $0 \mathrm{~h}$ were observed, while exposure to $2.0 \%$ bile concentration resulted in about 2-3 $\log$ reduction in viable count for most of the isolates. It was recorded that about 10 Bacillus isolates could tolerate at 1.0 and $2.0 \%$ bile concentrations even after 
exposure of $12 \mathrm{~h}$ suggesting that these Bacillus isolates could survive very well in bile in the small intestine. Around 3-4 log cycle reduction in viable count for most of the isolates was evident, as the exposure time increased upto $12 \mathrm{~h}$. This much reduction appeared to be quite reasonable at higher bile concentrations during long time exposure. Isolate B37 showed the highest tolerance to 2.0 percent bile salt concentration upto $12^{\text {th }} \mathrm{h}$ followed by B48, P3 and B9, while CR2 showed no survibility in the same conditions. The present results showed that Bacillus isolates survived well even at the higher bile concentration $(2.0 \%)$ than that of the bile concentrations $(0.4,0.3,0.2$ and $0.1 \%)$ used in earlier study (El-Naggar, 2004). The variability in response to bile salt tolerance is in agreement with the earlier report (Nithya and Halami, 2012).

\section{Surface hydrophobicity}

The observations on surface hydrophobicity of different Bacillus isolates are presented in table 2 . The results revealed a wide variation in hydrophobic interaction within Bacillus isolates. There was a considerable variation in the hydrophobicity of spores. Isolate T15 showed the highest adherence (48.43\%), followed by B37 (42.88\%) and B9 (37.43\%), while B48 had the least adherence ability $(9.13 \%)$. These findings are in agreement with the previous findings (Andersson et al., 1998). The variation in hydrophobicity to $\mathrm{N}$ hexadecane among different isolates could be explained by the fact that adhesion depended upon the origin of isolates as well as surface properties (Thwaite et al., 2009). The information regarding the hydrophobic interaction as well as adherence ability of the Bacillus spores and vegetative cells are very sparse, and it is also a contentious issue. Experiments on chicks revealed that after being given a single dose of $B$. subtilis spores, spores could persist for upto $36 \mathrm{~d}$ in the avian intestine (La Ragione and Woodward, 2003).
The S-layer proteins showed to function as adhesins to human epithelial cells and fibronectins (Hynonen et al., 2002), mouse ileal-epithelial cells (Frece et al., 2005).

The present study results probably suggest the ability of Bacillus isolates to adhere to intestinal epithelium for preventing immediate elimination by peristalsis as well as pathogen access by specific blockage on cell receptor or steric interactions (Otero et al., 2004).

\section{Rate of acid production}

The amount of lactic acid production (expressed in \% lactic acid) of different Bacillus isolates is documented in table 2 . Bacillus isolates collected from tomato sources have shown to produce lactic acid at the level between 0.98 and $1.23 \%$. B9, P3, and B37 were also capable of producing a considerable amount of acid $(0.74-0.87 \%)$ in growth medium within $24 \mathrm{~h}$, while $\mathrm{C} 8$ and B48 were very poor in this regard. There is a recent evidence of lactic acid production by B. coagulans from lignocelluloses (Ou et al., 2011). The lactic acid along with other acids like acetic acid could decrease the $\mathrm{pH}$ of the intestinal environment making it unsuitable for the survival and growth of different pathogenic and unwanted microorganisms (Lankapurtha and Shah, 1998).

\section{Comparative accounts on functional properties of Bacillus isolates}

The present study registered comparative accounts on functional properties of Bacillus isolates. Bacterial count at $\mathrm{pH} 3.0$ at $2 \mathrm{~h}$, bacterial count at $\mathrm{pH} 1.0$ at $1 \mathrm{~h}$, bacterial count at $2.0 \%$ bile concentration at $1 \mathrm{~h}$, bacterial count at $1.0 \%$ bile concentration at $12 \mathrm{~h}$, surface hydrophobicity and rate of acid production were identified as minimum data set (MDS) variables. 
Table.1 Acid tolerance ability of different Bacillus isolates

\begin{tabular}{|c|c|c|c|c|c|c|c|c|c|c|c|c|c|}
\hline \multirow[t]{2}{*}{$\begin{array}{l}\text { Sl. } \\
\text { No. }\end{array}$} & \multirow[t]{2}{*}{ Isolate } & \multicolumn{4}{|c|}{$\begin{array}{c}\text { Bacterial spore count (cfu) at } \\
\text { pH } 1.0\end{array}$} & \multicolumn{4}{|c|}{$\begin{array}{c}\text { Bacterial spore count (cfu) at } \\
\text { pH } 2.0\end{array}$} & \multicolumn{4}{|c|}{$\begin{array}{c}\text { Bacterial spore count (cfu) at } \\
\text { pH } 3.0\end{array}$} \\
\hline & & $\mathbf{0 h}$ & $1 \mathrm{~h}$ & $2 \mathrm{~h}$ & $3 \mathrm{~h}$ & $\mathbf{0 h}$ & $1 \mathrm{~h}$ & $2 h$ & $3 \mathbf{h}$ & oh & 1h & $2 \mathrm{~h}$ & $3 h$ \\
\hline 1 & B1 & 1.48 & 0.00 & 0.00 & 0.00 & 5.71 & 3.57 & 3.15 & 2.61 & 6.69 & 5.86 & 5.84 & 4.51 \\
\hline 2 & B4 & 3.61 & 2.51 & 2.11 & 0.00 & 6.86 & 5.49 & 4.18 & 3.85 & 7.90 & 6.54 & 6.11 & 4.60 \\
\hline 3 & B7 & 2.11 & 1.60 & 0.00 & 0.00 & 6.54 & 5.32 & 4.23 & 2.85 & 6.97 & 6.59 & 5.61 & 5.36 \\
\hline 4 & B9 & 6.32 & 5.67 & 3.51 & 2.11 & 7.86 & 7.36 & 6.23 & 5.85 & 7.96 & 7.59 & 7.18 & 6.87 \\
\hline 5 & B13 & 2.61 & 1.85 & 0.00 & 0.00 & 5.15 & 4.59 & 4.11 & 3.85 & 7.85 & 6.99 & 6.49 & 6.28 \\
\hline 6 & B15 & 1.85 & 0.00 & 0.00 & 0.00 & 4.91 & 4.69 & 4.18 & 3.90 & 5.88 & 5.67 & 5.11 & 4.83 \\
\hline 7 & B18 & 2.67 & 2.18 & 0.00 & 0.00 & 5.80 & 4.67 & 3.86 & 3.23 & 5.97 & 5.51 & 4.62 & 4.71 \\
\hline 8 & B30 & 0.00 & 0.00 & 0.00 & 0.00 & 4.23 & 2.95 & 3.71 & 3.95 & 6.63 & 5.49 & 5.69 & 8.90 \\
\hline 9 & B31 & 2.65 & 0.00 & 0.00 & 0.00 & 4.59 & 3.63 & 3.23 & 3.28 & 6.86 & 5.96 & 6.64 & 6.88 \\
\hline 10 & B32 & 2.97 & 0.00 & 0.00 & 0.00 & 5.92 & 4.65 & 3.30 & 4.32 & 6.18 & 5.90 & 6.49 & 6.65 \\
\hline 11 & B34 & 0.00 & 0.00 & 0.00 & 0.00 & 4.64 & 3.96 & 3.23 & 2.67 & 5.54 & 5.88 & 6.11 & 6.63 \\
\hline 12 & B37 & 3.69 & 2.23 & 0.00 & 0.00 & 6.18 & 5.85 & 5.28 & 5.36 & 6.81 & 6.73 & 6.53 & 6.11 \\
\hline 13 & B48 & 2.97 & 0.00 & 0.00 & 0.00 & 6.63 & 6.90 & 6.92 & 6.96 & 7.97 & 7.61 & 7.36 & 6.85 \\
\hline 14 & B51 & 4.23 & 0.00 & 0.00 & 0.00 & 6.68 & 5.90 & 5.79 & 5.11 & 6.72 & 6.97 & 7.23 & 7.36 \\
\hline 15 & B58 & 0.00 & 0.00 & 0.00 & 0.00 & 4.97 & 3.62 & 2.97 & 0.00 & 5.59 & 4.67 & 3.86 & 2.61 \\
\hline 16 & C3 & 0.00 & 0.00 & 0.00 & 0.00 & 5.26 & 5.73 & 5.97 & 5.90 & 6.95 & 7.11 & 6.93 & 6.99 \\
\hline 17 & $\mathrm{C} 4$ & 2.60 & 1.85 & 0.00 & 0.00 & 4.20 & 4.28 & 4.32 & 4.73 & 6.73 & 5.86 & 4.57 & 4.97 \\
\hline 18 & C6 & 0.00 & 0.00 & 0.00 & 0.00 & 4.90 & 4.23 & 3.91 & 3.73 & 5.18 & 5.43 & 5.80 & 5.95 \\
\hline 19 & C8 & 3.81 & 3.15 & 2.70 & 0.00 & 7.28 & 7.36 & 6.23 & 6.28 & 7.48 & 7.69 & 7.58 & 7.94 \\
\hline 20 & C14 & 2.15 & 0.00 & 0.00 & 0.00 & 3.95 & 4.23 & 3.90 & 4.38 & 5.15 & 4.97 & 4.94 & 4.85 \\
\hline 21 & P3 & 3.56 & 2.18 & 0.00 & 0.00 & 6.62 & 6.28 & 5.48 & 5.32 & 6.90 & 6.57 & 6.15 & 5.95 \\
\hline 22 & $\mathrm{P} 4$ & 3.88 & 2.73 & 0.00 & 0.00 & 4.65 & 3.40 & 2.84 & 0.00 & 4.84 & 4.66 & 3.40 & 3.11 \\
\hline 23 & P5 & 3.15 & 1.99 & 2.05 & 0.00 & 3.97 & 3.15 & 2.73 & 1.60 & 5.32 & 5.64 & 4.97 & 4.95 \\
\hline 24 & P8 & 0.00 & 0.00 & 0.00 & 0.00 & 4.67 & 4.97 & 5.02 & 5.60 & 6.63 & 6.87 & 6.97 & 7.32 \\
\hline \multirow[t]{2}{*}{$\begin{array}{l}\text { Sl. } \\
\text { No. }\end{array}$} & \multirow[t]{2}{*}{ Isolate } & \multicolumn{4}{|c|}{$\begin{array}{c}\text { Bacterial spore count (cfu) at } \\
\text { pH } 1.0\end{array}$} & \multicolumn{4}{|c|}{$\begin{array}{c}\text { Bacterial spore count (cfu) at } \\
\text { pH } 2.0\end{array}$} & \multicolumn{4}{|c|}{$\begin{array}{c}\text { Bacterial spore count (cfu) at } \\
\text { pH } 3.0\end{array}$} \\
\hline & & oh & $1 \mathrm{~h}$ & $2 \mathrm{~h}$ & $3 h$ & oh & $1 \mathrm{~h}$ & $2 \mathrm{~h}$ & $3 h$ & oh & $1 \mathrm{~h}$ & $2 \mathrm{~h}$ & $3 h$ \\
\hline 25 & P9 & 2.81 & 0.00 & 0.00 & 0.00 & 4.86 & 4.77 & 4.23 & 4.67 & 5.91 & 5.97 & 6.23 & 6.08 \\
\hline 26 & P10 & 5.96 & 3.23 & 2.59 & 0.00 & 4.83 & 3.97 & 3.73 & 3.51 & 6.93 & 6.54 & 4.60 & 5.26 \\
\hline 27 & P12 & 3.20 & 0.00 & 0.00 & 0.00 & 6.73 & 6.51 & 5.67 & 4.08 & 7.59 & 6.86 & 6.99 & 6.26 \\
\hline 28 & $\mathrm{P} 17$ & 2.98 & 0.00 & 0.00 & 0.00 & 5.19 & 4.28 & 3.64 & 2.93 & 5.80 & 5.76 & 4.78 & 2.23 \\
\hline 29 & SM2 & 0.00 & 0.00 & 0.00 & 0.00 & 2.97 & 2.08 & 0.00 & 0.00 & 4.11 & 3.30 & 2.66 & 0.00 \\
\hline 30 & SM5 & 2.62 & 0.00 & 0.00 & 0.00 & 3.56 & 3.15 & 2.95 & 2.26 & 3.88 & 3.18 & 3.90 & 3.65 \\
\hline 31 & SM7 & 2.65 & 0.00 & 0.00 & 0.00 & 4.90 & 4.68 & 4.41 & 4.96 & 5.91 & 5.77 & 4.86 & 4.61 \\
\hline 32 & CR2 & 3.20 & 2.95 & 2.66 & 0.00 & 6.75 & 6.63 & 6.28 & 6.23 & 7.91 & 7.86 & 7.54 & 6.60 \\
\hline 33 & CR5 & 2.23 & 2.45 & 0.00 & 0.00 & 4.65 & 4.97 & 3.57 & 3.85 & 5.90 & 5.71 & 5.51 & 4.48 \\
\hline 34 & CR8 & 0.00 & 0.00 & 0.00 & 0.00 & 3.73 & 3.97 & 4.04 & 4.56 & 5.18 & 5.86 & 5.97 & 5.75 \\
\hline 35 & CR10 & 0.00 & 0.00 & 0.00 & 0.00 & 5.32 & 4.51 & 3.63 & 2.28 & 6.85 & 5.95 & 5.74 & 5.20 \\
\hline 36 & CR11 & 2.70 & 2.60 & 0.00 & 0.00 & 4.87 & 4.97 & 5.06 & 4.99 & 5.43 & 5.85 & 6.04 & 6.51 \\
\hline 37 & $\mathrm{~T} 4$ & 0.00 & 0.00 & 0.00 & 0.00 & 6.81 & 6.51 & 5.30 & 5.61 & 7.97 & 7.85 & 6.28 & 6.32 \\
\hline 38 & $\mathrm{~T} 7$ & 2.95 & 2.77 & 0.00 & 0.00 & 4.43 & 3.65 & 3.97 & 3.45 & 4.23 & 4.73 & 4.97 & 4.08 \\
\hline 39 & T15 & 3.87 & 3.69 & 2.54 & 0.00 & 5.18 & 4.28 & 4.38 & 4.99 & 6.91 & 6.61 & 6.23 & 5.49 \\
\hline 40 & T19 & 3.23 & 3.72 & 2.90 & 0.00 & 5.73 & 5.89 & 5.91 & 5.20 & 6.96 & 6.56 & 5.79 & 4.52 \\
\hline 41 & $\mathrm{~T} 23$ & 3.73 & 2.89 & 2.28 & 0.00 & 5.62 & 4.97 & 4.43 & 4.08 & 6.76 & 6.91 & 6.28 & 6.38 \\
\hline 42 & S1 & 0.00 & 0.00 & 0.00 & 0.00 & 3.65 & 2.51 & 0.00 & 0.00 & 4.23 & 4.63 & 3.89 & 3.61 \\
\hline 43 & $\mathrm{~S} 2$ & 2.88 & 0.00 & 0.00 & 0.00 & 4.69 & 2.89 & 2.28 & 0.00 & 6.04 & 5.93 & 4.23 & 3.62 \\
\hline 44 & S5 & 0.00 & 0.00 & 0.00 & 0.00 & 4.04 & 3.61 & 0.00 & 0.00 & 5.86 & 4.97 & 2.76 & 0.00 \\
\hline 45 & S9 & 2.90 & 2.61 & 0.00 & 0.00 & 4.92 & 3.85 & 2.28 & 0.00 & 5.26 & 4.64 & 4.28 & 3.61 \\
\hline 46 & $\mathrm{~S} 10$ & 2.96 & 0.00 & 0.00 & 0.00 & 4.07 & 3.64 & 2.96 & 0.00 & 4.57 & 4.62 & 3.15 & 0.00 \\
\hline 47 & $\mathrm{~S} 13$ & 4.73 & 2.99 & 2.59 & 0.00 & 4.63 & 4.28 & 3.34 & 2.61 & 5.59 & 4.63 & 4.23 & 3.28 \\
\hline
\end{tabular}


Table.2 Bile tolerance ability, adherence and acid production performance of Bacillus isolates

\begin{tabular}{|c|c|c|c|c|c|c|c|c|c|c|c|}
\hline \multirow[t]{2}{*}{ Sl. No. } & \multirow[t]{2}{*}{ Isolate } & \multicolumn{4}{|c|}{$\begin{array}{c}\text { Bacterial spore count }(\text { cfu) at } 1.0 \% \\
\text { bile }\end{array}$} & \multicolumn{4}{|c|}{$\begin{array}{c}\text { Bacterial spore count }(\text { cfu) at } 2.0 \% \\
\text { bile }\end{array}$} & \multirow{2}{*}{$\begin{array}{c}\text { Adherence } \\
(\%)\end{array}$} & \multirow{2}{*}{$\begin{array}{c}\text { Acid } \\
\text { Production } \\
(\%)\end{array}$} \\
\hline & & oh & 1h & $3 h$ & $12 \mathrm{~h}$ & oh & $1 \mathrm{~h}$ & $3 h$ & $12 \mathrm{~h}$ & & \\
\hline 1 & B1 & 6.46 & 6.11 & 4.86 & 3.81 & 5.28 & 4.62 & 3.48 & 2.53 & 19.48 & 0.63 \\
\hline 2 & B4 & 5.86 & 5.40 & 4.69 & 2.51 & 4.71 & 3.65 & 2.91 & 0.00 & 49.19 & 0.71 \\
\hline 3 & B7 & 5.11 & 3.87 & 2.94 & 0.00 & 2.82 & 0.00 & 0.00 & 0.00 & 07.02 & 0.51 \\
\hline 4 & B9 & 6.43 & 5.95 & 5.64 & 6.28 & 5.70 & 5.36 & 4.59 & 4.87 & 37.43 & 0.73 \\
\hline 5 & B13 & 5.11 & 5.62 & 4.54 & 3.38 & 3.46 & 3.60 & 3.41 & 3.08 & 44.42 & 0.67 \\
\hline 6 & B15 & 5.51 & 4.32 & 3.96 & 3.18 & 3.11 & 2.61 & 2.34 & 2.37 & 08.18 & 0.43 \\
\hline 7 & B18 & 6.60 & 6.51 & 5.90 & 5.43 & 6.53 & 6.23 & 5.60 & 5.51 & 14.37 & 0.37 \\
\hline 8 & B30 & 5.28 & 4.86 & 4.28 & 3.95 & 4.30 & 3.32 & 2.30 & 2.32 & 12.27 & 1.13 \\
\hline 9 & B31 & 6.59 & 5.86 & 5.76 & 4.93 & 5.18 & 5.40 & 5.30 & 4.38 & 06.04 & 0.80 \\
\hline 10 & B32 & 7.48 & 6.45 & 5.08 & 5.26 & 7.85 & 5.30 & 4.48 & 4.18 & 10.58 & 0.54 \\
\hline 11 & B34 & 7.63 & 5.49 & 4.62 & 4.15 & 5.23 & 4.86 & 4.23 & 4.32 & 16.12 & 0.62 \\
\hline 12 & B37 & 7.46 & 6.11 & 6.86 & 6.81 & 6.28 & 5.62 & 5.48 & 5.53 & 42.88 & 0.67 \\
\hline 13 & B48 & 7.49 & 6.60 & 7.23 & 7.04 & 6.18 & 6.32 & 5.85 & 5.30 & 09.13 & 0.19 \\
\hline 14 & B51 & 5.46 & 3.75 & 3.08 & 1.95 & 3.65 & 2.36 & 0.00 & 0.00 & 06.73 & 0.71 \\
\hline 15 & B58 & 6.99 & 6.91 & 6.38 & 5.60 & 5.49 & 5.18 & 5.63 & 4.46 & 09.10 & 0.47 \\
\hline 16 & C3 & 5.69 & 4.52 & 4.86 & 4.95 & 4.51 & 4.60 & 4.76 & 4.85 & 51.20 & 0.19 \\
\hline 17 & $\mathrm{C} 4$ & 6.59 & 6.11 & 6.15 & 6.49 & 6.15 & 5.62 & 5.59 & 5.99 & 19.81 & 0.62 \\
\hline 18 & C6 & 5.48 & 5.38 & 4.71 & 3.85 & 4.23 & 3.08 & 2.32 & 0.00 & 32.90 & 0.67 \\
\hline 19 & C8 & 4.30 & 4.73 & 4.18 & 4.28 & 3.70 & 3.57 & 3.86 & 3.23 & 38.33 & 0.19 \\
\hline 20 & $\mathrm{C} 14$ & 6.08 & 5.11 & 6.04 & 6.11 & 5.20 & 5.00 & 5.95 & 5.85 & 17.29 & 0.72 \\
\hline 21 & P3 & 6.65 & 6.43 & 7.66 & 5.75 & 6.57 & 5.15 & 6.18 & 4.99 & 27.38 & 0.76 \\
\hline 22 & $\mathrm{P} 4$ & 3.65 & 2.48 & 3.23 & 4.59 & 0.00 & 0.00 & 0.00 & 0.00 & 19.10 & 0.60 \\
\hline 23 & P5 & 4.32 & 4.85 & 3.64 & 3.73 & 2.64 & 2.29 & 2.43 & 2.78 & 18.40 & 0.58 \\
\hline 24 & P8 & 5.87 & 4.62 & 3.58 & 3.28 & 3.56 & 2.89 & 2.08 & 0.00 & 51.50 & 0.72 \\
\hline \multirow[t]{2}{*}{$\begin{array}{l}\text { Sl. } \\
\text { No. }\end{array}$} & \multirow[t]{2}{*}{ Isolate } & \multicolumn{4}{|c|}{$\begin{array}{l}\text { Bacterial spore count (cfu) at } \\
\mathbf{1 . 0 \%} \text { bile }\end{array}$} & \multicolumn{4}{|c|}{$\begin{array}{l}\text { Bacterial spore count (cfu) at } \\
\mathbf{2 . 0 \%} \text { bile }\end{array}$} & \multirow{2}{*}{$\begin{array}{c}\text { Adherence } \\
\qquad(\%)\end{array}$} & \multirow{2}{*}{$\begin{array}{c}\text { Acid } \\
\text { Production } \\
(\%)\end{array}$} \\
\hline & & $\mathbf{0 h}$ & $1 \mathrm{~h}$ & $3 \mathbf{h}$ & $12 \mathrm{~h}$ & oh & $1 \mathrm{~h}$ & $3 h$ & $12 \mathrm{~h}$ & & \\
\hline 25 & P9 & 3.87 & 3.23 & 3.48 & 3.65 & 0.00 & 0.00 & 0.00 & 0.00 & 11.01 & 0.79 \\
\hline 26 & $\mathrm{P} 10$ & 4.79 & 2.60 & 2.20 & 0.00 & 3.65 & 0.00 & 0.00 & 0.00 & 42.37 & 0.57 \\
\hline 27 & P12 & 5.75 & 3.88 & 3.53 & 2.26 & 4.59 & 2.61 & 2.08 & 0.00 & 22.44 & 0.59 \\
\hline 28 & P17 & 6.65 & 4.20 & 3.38 & 2.90 & 3.11 & 2.63 & 0.00 & 0.00 & 15.58 & 0.57 \\
\hline 29 & SM2 & 8.61 & 8.77 & 8.38 & 6.00 & 7.56 & 6.00 & 7.73 & 6.48 & 22.91 & 0.51 \\
\hline 30 & SM5 & 5.48 & 3.30 & 0.00 & 0.00 & 5.60 & 3.11 & 0.00 & 0.00 & 27.93 & 0.60 \\
\hline 31 & SM7 & 7.52 & 6.28 & 6.85 & 6.23 & 8.64 & 6.95 & 7.57 & 7.28 & 14.89 & 0.65 \\
\hline 32 & CR2 & 6.28 & 5.38 & 4.45 & 2.85 & 5.85 & 4.63 & 2.86 & 0.00 & 27.42 & 0.11 \\
\hline 33 & CR5 & 6.65 & 5.49 & 3.11 & 0.00 & 6.53 & 4.99 & 2.32 & 0.00 & 16.84 & 0.13 \\
\hline 34 & CR8 & 4.48 & 4.15 & 4.57 & 5.38 & 3.08 & 2.85 & 3.65 & 3.95 & 17.81 & 0.12 \\
\hline 35 & CR10 & 3.20 & 3.15 & 2.86 & 2.60 & 0.00 & 0.00 & 0.00 & 0.00 & 12.19 & 0.60 \\
\hline 36 & CR11 & 4.95 & 4.49 & 5.73 & 6.00 & 3.62 & 3.85 & 4.49 & 4.97 & 15.04 & 0.11 \\
\hline 37 & $\mathrm{~T} 4$ & 6.28 & 5.60 & 5.78 & 5.51 & 4.63 & 3.95 & 3.70 & 3.00 & 06.94 & 0.49 \\
\hline 38 & $\mathrm{~T} 7$ & 7.75 & 7.57 & 6.90 & 6.79 & 5.97 & 5.62 & 4.53 & 4.15 & 20.22 & 1.06 \\
\hline 39 & T15 & 6.95 & 6.73 & 6.86 & 4.51 & 7.73 & 5.08 & 3.90 & 2.96 & 48.43 & 1.22 \\
\hline 40 & T19 & 7.23 & 6.65 & 5.85 & 5.04 & 6.85 & 5.59 & 5.18 & 3.70 & 16.05 & 0.99 \\
\hline 41 & T23 & 5.70 & 6.18 & 5.45 & 3.46 & 5.49 & 4.49 & 3.11 & 2.71 & 37.42 & 0.98 \\
\hline 42 & $\mathrm{~S} 1$ & 6.59 & 5.69 & 4.97 & 0.00 & 3.30 & 2.60 & 0.00 & 0.00 & 08.40 & 0.46 \\
\hline 43 & $\mathrm{~S} 2$ & 4.85 & 3.60 & 2.30 & 1.23 & 4.15 & 3.36 & 0.00 & 0.00 & 18.53 & 0.11 \\
\hline 44 & S5 & 5.70 & 5.23 & 4.43 & 3.15 & 4.04 & 3.30 & 2.95 & 0.00 & 17.89 & 0.43 \\
\hline 45 & S9 & 7.23 & 4.97 & 4.23 & 3.95 & 6.49 & 3.61 & 2.73 & 2.38 & 28.33 & 0.12 \\
\hline 46 & S10 & 6.36 & 5.23 & 4.96 & 3.23 & 4.61 & 3.40 & 2.18 & 0.00 & 13.42 & 0.76 \\
\hline 47 & S13 & 6.86 & 5.64 & 4.67 & 3.23 & 5.57 & 3.85 & 3.56 & 2.15 & 14.21 & 0.60 \\
\hline
\end{tabular}


Fig.1 A comparative accounts for resistance to acid, tolerance to bile salt, cell surface hydrophobicity and rate of acid production of the selected Bacillus isolates

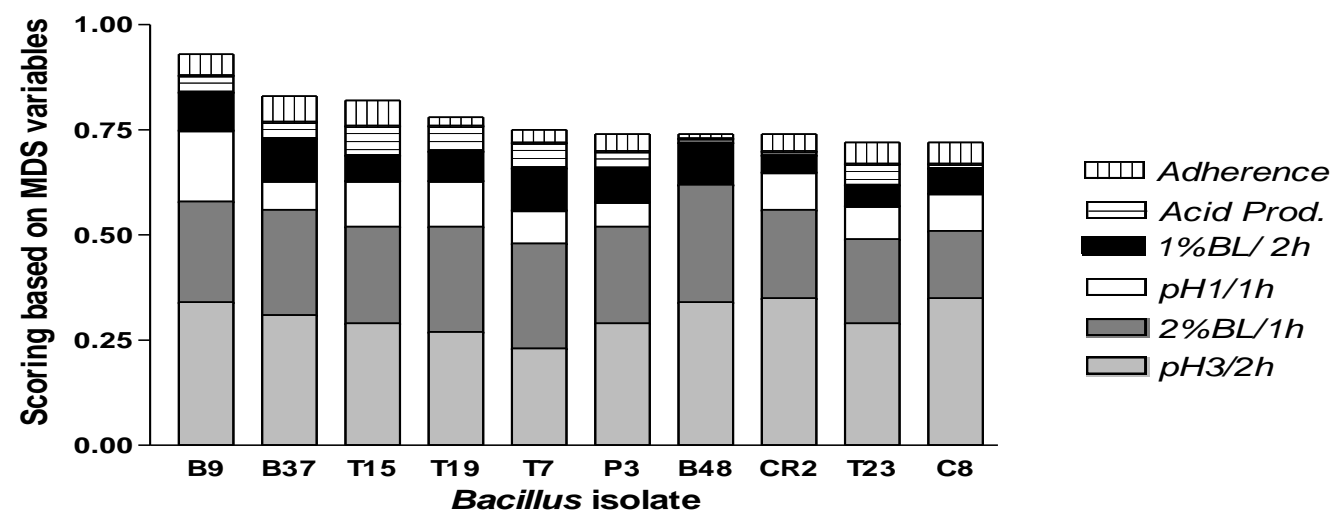

Considering one criterion that highest value was best for each MDS variable, first ten Bacillus isolates were ranked on the basis of total weighted linear scoring as presented in Fig. 1. Based on weighted linear scoring on the minimum data set (MDS) of variables, isolate B9, isolate B37 and isolate T15 were ranked first, second and third, respectively.

In conclusion, the present study revealed a considerable variability among different Bacillus isolates for acid tolerance, bile salt tolerance, cell surface hydrophobicity and rate of acid production potential. A multivariate principal component analysis with a varimax procedure of factor analysis and weighted linear scoring on the minimum data set of variables registered a ranking of Bacillus isolates for the functional properties of probiotics.

\section{Acknowledgement}

The authors acknowledge the financial assistance and necessary supports provided by the Director of National Dairy Research Institute, Karnal, Haryana, India to carry out the study. The first author wishes to express her sincere thanks to Dr. Rameshwar Singh, Project Director, ICAR-Directorate of Knowledge Management in Agriculture, Indian Council of Agricultural Research, Krishi Anusandhan Bhawan-I, Pusa, New Delhi, India for his constant help and suggestions during the investigation at Dairy Microbiology Division,
National Dairy Research Institute, Karnal, Haryana, India.

\section{References}

Andersson, A., Granum, P.E., Ronner, U. 1998. The adhesion of Bacillus cereus spores to epithelial cells might be an additional virulence mechanism. Int. J. Food Microbiol., 39: 93-99.

Atlas, R.M. 2004. Handbook of microbiological media. 3rd edn. Taylor \& Francis, Boca Raton.

Baick, S.C., Kim, C.H. 2015. Assessment of Characteristics and Functional Properties of LactoBacillus Species Isolated from Kimchi for Dairy Use. Korean J. Food Sci. Anim. Resour., 35(3): 339-349.

Clark, P.A., Cotton, L.N., Martin, J.H. 1993. Selection of Bifidobacteria for use as dietary adjuncts in cultured dairy foods: II. Tolerance to simulated $\mathrm{pH}$ of human stomachs. Cult. Dairy Prod. J., 28: 11-14.

Clark, P.A., Martin, J.H. 1994. Selection of Bifidobacteria for use as dietary adjuncts in cultured dairy foods: III. Tolerance to simulated bile concentrations of human small intestines. Cult. Dairy Prod. J., 29: 20-21.

Cutting, S.M. 2011. Bacillus probiotics. Food Microbiol., 28: 214-220.

El-Naggar, M.Y.M. 2004. Comparative study of probiotic cultures to control the growth of Escherichia coli O157: H7 and Salmonella typhimurium. Biotechnol., 3: 173-180.

FAO/WHO. 2002. Guidelines for the evaluation 
of probiotics in food. Report of a joint FAO/WHO working group on drafting guidelines for evaluation of probiotics in food, London, Ontario, Canada. April 30 and May 1, 2002.

Fontana, L., Bermudez-Brito, M., Plaza-Diaz, J., Muñoz-Quezada, S., Gil, A. 2013. Sources, isolation, characterisation and evaluation of probiotics. Br. J. Nutr., 109 Suppl 2: S3550.

Frece, I., Kos, B., Svetec, I.K., Zgaga, Z., Mrsa, V., Suskovic, J. 2005. Importance of Slayer proteins in probiotic activity of LactoBacillus acidophilus M92. J. Appl. Microbiol., 98: 285-292.

Haldar, L., Gandhi, D.N., Majumdar, D., De, S. 2015. Characterization of indigenous Bacillus coagulans isolated from cattle and buffalo milk. Int. J. Microbiol. Res., 7: 686691.

Hong, H.A., Duc, L.H., Cutting, S.M. 2005. The use of bacterial spore formers as probiotics. FEMS Microbiol. Rev., 29: 813-835.

Hynonen, U., Westerlund-Wikstrom, B., Palva, A., Korhonen, T.K. 2002. Fibronectinbinding function in the SlpA surface protein of LactoBacillus brevis. J. Bacteriol., 184: 3360-3367.

Hyronimus, B., Le Marrec, C., Hadj Sassi, A., Deschamps, A. 2000. Acid and bile tolerance of sporeforming lactic acid bacteria. Int. J. Food Microbiol., 61: 193197.

Jurenka, J.S. 2012. Bacillus coagulans. Altern. Med. Rev., 17: 76-81.

Kumari, A., Catanzaro, R., Marotta, F. 2011. Clinical importance of lactic acid bacteria: a short review. Acta Bio-medica., 82: 177180.

La Ragione, R.M., Woodward, M. 2003. Competitive exclusion by Bacillus subtilis spores of Salmonella enterica serotype enteritidis and Clostridium perfringens in young chickens. Vet. Microbiol., 94: 245256.

Lankapurtha, W.E., Shah, N.P. 1998. Adherence of probiotic bacteria to human colonic cells. Biosci. Microflora, 17: 105-113.

Nithya, V., Halami, P.M. 2012. Evaluation of the probiotic characteristics of Bacillus species isolated from different food sources. Ann. Microbiol., doi:10.1007/s13213-012-04534.

Otero, M.C., Ocana, V.S., Nader-Macias, E.M. 2004. Bacterial surface characteristics applied to selection of probiotic microorganisms. Meth. Mol. Biol., 268: 435-440.

Ou, M.S., Ingram, L.O., Shanmugam, K.T. 2011. $\mathrm{L}(+)$-Lactic acid production from non-food carbohydrates by thermotolerant Bacillus coagulans. J. Indust. Microbiol. Biotechnol., 38: 599-605.

Rosenberg, M., Gutwick, D., Rosenberg, E. 1980. Adherence of bacteria to hydrocarbons: A simple method for measuring cell surface hydrophobicity. FEMS Microbiol. Lett., 9: 29-33.

Shobharani, P., Halami, P.M. 2014. Cellular fatty acid profile and $\mathrm{H}(+)$-ATPase activity to assess acid tolerance of Bacillus sp. for potential probiotic functional attributes. Appl. Microbiol. Biotechnol., 98(21): 90459058.

Sidira, M., Kandylis, P., Kanellaki, M., Kourkoutas, Y. 2015. Effect of immobilized LactoBacillus casei on the evolution of flavor compounds in probiotic dry-fermented sausages during ripening. Meat Sci., 100:41-51. doi: 10.1016/j.meatsci.2014.09.011.

Thwaite, J.E., Laws, T.R., Atkins, T.P., Atkins, H.S. 2009. Differential cell surface properties of vegetative Bacillus. Lett. Appl. Microbiol., 48(3): 373-378.

\section{How to cite this article:}

Lopamudra Haldar, D.N. Gandhi and Debasis Mazumdar. 2017. Functional Properties of SporeForming Bacillus Strains: Pre-requisite for Probiotic Functions. Int.J.Curr.Microbiol.App.Sci. 6(2): 162-169. doi: http://dx.doi.org/10.20546/ijcmas.2017.602.023 